\section{PROPOSED REGULATION OF THIRD-PARTY FUNDING IN INVESTOR-STATE DISPUTE SETTLEMENT}

\section{Matias Tamlander ${ }^{1}$}

\section{DOI: https://doi.org/10.33344/vol14iss1pp74-87}

Helsinki Law Review, 1/2020, pp. 74-87

(c) 2020 Pykälä ry, Mannerheimintie 3 B, 5th floor, 00100 Helsinki, Finland, and the author.

\section{Keywords:}

international investment law, investor-state dispute settlement, third-party funding, ICSID, UNCITRAL

\section{ABSTRACT}

Third-party litigation funding is increasingly used to finance legal claims in investor-state dispute settlement, with financiers funding investor claims against sovereign states in exchange for a share of potentially substantial compensation rendered in eventual arbitral awards. A chiefly unregulated phenomenon, third-party funding has been perceived especially controversial in the context of the investment arbitration regime, a system some allege is already ingrained with inequities.

Third-party funding raises numerous policy questions, such as conflicts of interests, disclosure, costs of the proceedings, and even the entire permissibility of the practice in investor-state dispute settlement. This review raises various issues and concerns related to third-party funding in investor-state dispute settlement and presents the regulatory efforts and criticism thereof with regards to the reform of rules of both the International Centre for Settlement of Investment Disputes and the United Nations Commission on International Trade Law.

\section{INTRODUCTION}

The international system of investment protection has attracted a great deal of interest in legal literature and public debate in the twenty-first century. Since the 1960 s, various bilateral (BIT) and multilateral investment treaties have been negotiated between countries around the world to regulate cross-border investment. ${ }^{2}$ These treaties almost invariably contain a dispute settlement clause, on the basis of which the investor may refer possible disputes to arbitration. Such arbitration proceeding is known as investor-state dispute settlement (ISDS). In ISDS, the investor may, for instance, dispute whether legal reforms, amendments or administrative actions implemented by the investment host state are in breach of the investment treaty said state has signed. For investors, the economic and legal stability of the host state is a crucial condition of the investment, and investments made may also be of considerable magnitude for the economy of the host state. The purpose of ISDS has been to protect foreign investors from arbitrary state policies. ${ }^{3}$ Today, the overall fairness of ISDS and motives of investors in raising claims have been under increasing academic and political scrutiny, as nearly half of known concluded ISDS cases have been decided in favour of the investor or settled, typically by unknown terms. ${ }^{4}$

The value of the arbitration award rendered to the investor in ISDS cases has averaged around EUR 473 million, ${ }^{5}$ with a claim success rate of approximately $29.4 \% .^{6}$ The average cost of the ISDS proceeding to the claimant investor has been EUR 6.5 million, while that of the respondent state has on average been EUR 4.65 million. ${ }^{7}$ ISDS is thus a very expensive and high-risk process for both the investors and states. Before the end of the 1990s, there had only been fourteen International Centre for Settlement of Investment Disputes (ICSID) ISDS proceedings during the four decades of investment treaty regime, ${ }^{8}$ after which the number of ICSID cases has skyrocketed to over 600 cases by $2020 .^{9}$ This may be explained, to some extent, by the rapid increase in the number of BITs during the 1990s, when their number increased fivefold. ${ }^{\mathbf{1 0}}$ The rise of cases may also continue as investors see their investments threatened by, for example,

2 United Nations Commission on International Trade Law (UNCTAD): Bilateral Investment Treaties 1959 1999, UNCTAD/ITE/IIA/2, 2000 (UNCTAD 2000).

Dolzer, Rudolf - Schreuer, Christoph: Principles of International Investment Law. 2nd edition, Oxford University Press, 2012 (Dolzer - Schreuer 2012), p. 1-6.

4 UNCTAD: Investment Dispute Settlement Navigator, https://investmentpolicy.unctad.org/investmentdispute-settlement (UNCTAD 2020). Accessed 7 November 2020

5 Average of all known ISDS cases by 31 July 2017. UNCTAD: Special Update on Investor-State Dispute Settlement: Facts and Figures, 2017, p. 1.

6 Of all ISDS cases known to date. UNCTAD 2020

7 Hodgson, Matthew - Campbell, Alastair: Damages and Costs in Investment Treaty Arbitration Revisited. Global Arbitration Review, December 2017, https://globalarbitrationreview.com/damages-and-costsin-investment-treaty-arbitration-revisited.

8 Dolzer - Schreuer 2012, p. 111

9 UNCTAD 2020.

10 UNCTAD 2000, p. 1 
climate change action curbing the use of fossil fuels. ${ }^{11}$ Times of crisis have often led to a surge in ISDS claims, and the ongoing COVID-19 pandemic is no exception as governments around the globe take action to combat the virus. ${ }^{\mathbf{1 2}}$

There is a growing demand for financing of expensive ISDS lawsuits with third-party funding (TPF), and investors suing states are able to turn to financiers to pay for their litigation. Dispute financing services enable the commodification of an ISDS claim that may be offered to international financial markets. ${ }^{13}$ The third-party funder usually receives a compensation for the financial risk it takes in an ISDS lawsuit. This compensation consists of either a part or the entirety of the financial compensation rendered in the arbitration award. Litigation finance services may be very attractive to the claimant, as they allow monetisation of potential assets that are not easily accounted for or securitised and flexible financing of a generally expensive ISDS claim. ${ }^{14}$ As investors and financiers have identified the potential of ISDS, TPF has garnered attention as states face a growing caseload questioning their policy choices. Particular attention has been paid to whether TPF increases financing of frivolous investor cases against bona fide state actions.

This review will firstly present the brief history, current status and impact of TPF in ISDS, including concerns related to the practice, as well as set out the main lines of development of the rules that aim to regulate TPF in ISDS. Furthermore, this review will display criticism among various ICSID member states that the rules reform of ICSID has provoked. Lastly, the review will also introduce opinions of ISDS TPF regulation presented during the similar but separate rules amendment process of the United Nations Commission on International Trade Law (UNCITRAL).

11 Tienhaara, Kyla: Regulatory Chill in a Warming World: The Threat to Climate Policy Posed by InvestorState Dispute Settlement. Transnational Environmental Law, Cambridge University Press, 2017, p. 229-233. Some scholars argue that ISDS causes "regulatory chill" (i.e. a hypothesis that states fail to regulate various issues of public interest due to the threat of ISDS)

12 See e.g. Columbia Center on Sustainable Investment: Call for ISDS Moratorium During COVID-19 Crisis and Response 6 May 2020 http://ccsi.columbia.edu/2020/05/05/isds-moratorium-during-covid-19/. Accessed 7 November 2020

13 International Council for Commercial Arbitration: Report of the ICCA-Queen Mary task force on thirdparty funding in international arbitration, 2018 (ICCA-Queen Mary 2018), p. 37.

14 Guven, Brooke - Johnson, Lise: The Policy Implications of third-party funding in Investor-State Dispute Settlement, Columbia Center on Sustainable Investment Working Paper, 2019 (Guven - Johnson 2019), p. 1.

\section{TPF IN ISDS AND ITS IMPACT ON PROCEEDINGS}

\section{I Definition of TPF}

The involvement of third parties in other people's disputes is not a novel practice, as its roots date back to early civil law jurisdictions. ${ }^{15}$ In its current form, TPF in ISDS has however remained largely unregulated. ${ }^{16}$ Traditionally, TPF has been banned in common law jurisdictions under prohibitions against maintenance and champerty, whereas in civil law jurisdictions the practice has attracted little regulatory attention. ${ }^{17}$ Contemporary regulation of TPF in ISDS is sparse and fragmented, although in some recent trade agreements the scheme has been regulated. For the most part, TPF has been allowed in investment treaties and agreements, ${ }^{18}$ while in some treaties it has been completely banned in ISDS. ${ }^{19}$

TPF is a contractual arrangement defined and agreed upon in the funding agreement between the financier and the party to the dispute. The funder financier has myriad options to finance the litigation, for example in the form of insurance, loan, corporate finance, capital investment purchase of a company's securities, donation, or as a representation agreement, as long as the purpose of the funding is to generate a profit for the funder through a successful ISDS claim. ${ }^{20}$ The funding is usually channelled through a special purpose vehicle (SPV) that is established to limit the financial liability of the funder. ${ }^{\mathbf{2 1}}$ These legal entities are usually created and registered in tax havens. ${ }^{22}$

15 Solas, Gian Marco: Third party funding: Law, economics, and policy. Cambridge: Cambridge University Press, 2019, p. 18

16 See e.g. UNCITRAL: A/CN.9/WG.III/WP.172, August 2019, p. 3.

17 Guven - Johnson 2019, p. 15.

18 Hong Kong and Singapore, for example, have repealed regulations that prevented the use of TPF in arbitration proceedings. Furthermore, the free-trade agreement between Canada and EU (CETA) allows the use of TPF under certain conditions.

19 Guven - Johnson 2019, p. 39. TPF is completely prohibited, for instance, in the BIT between Argentina and the United Arab Emirates.

20 ICCA-Queen Mary 2018, p. 33-37.

21 See e.g. Guven - Johnson 2019, p. 5 and Veljanovski, Cento: Third-Party Litigation Funding in Europe. The Journal of Law, Economics \& Policy, George Mason University School of Law, Volume 8, Number 3, 2012 (Veljanovski 2012), p. 430. SPV's are companies that are separate from the financier company and are usually established for tax and insolvency reasons. The financier company may limit its liability of an adverse costs award with an SPV.

22 Ibid 
Because of lack of regulation, TPF has not been defined in the most used ISDS arbitration rules, the ICSID and UNCITRAL rules. ${ }^{23}$ Due to diversity of financial instruments and virtually endless possible forms of funding, a comprehensive definition is difficult to create. ${ }^{24}$ Regulation in the most used arbitration rules would be needed to ensure a harmonised process in ISDS proceedings. In the extensive ICCA-Queen Mary-report carried out by the International Council for Commercial Arbitration (ICCA), a multifaceted definition of a TPF contract is proposed:

"a contract or agreement by a party or potential party to dispute resolution proceedings with a Third-Party Funder for the funding of all or part of the costs of the proceedings in return for a share or other interest in the proceeds or potential proceeds of the proceedings to which the party or potential party may become entitled."25

The report also states that it would be appropriate to create a broad definition of the term so as not to exclude forms of financing from the scope and to toughen circumvention of the regulation. ${ }^{26}$

\subsection{Impact of TPF on ISDS}

\subsubsection{Background}

TPF in ISDS has grown vastly in popularity since the last millennia. ${ }^{27}$ Its rise in popularity has been estimated to be largely due to financial risk management, as particularly small and medium-sized enterprise investors often lack the funds required to go through expensive ISDS proceedings. ${ }^{\mathbf{2 8}}$ Lack of funds makes it popular to refer to the basic principle of access to justice when justifying use of TPF, ${ }^{29}$ although the investor often retains the possibility to bring the claim before a national court, a process which would not require as much funds as arbitration proceedings. $^{30}$ The investor may want to have the case heard before an arbitral tribunal for various reasons, e.g. the proceeding is generally not public, the investor has the opportunity to influence the choice of arbitrators, and the investor may not want the case to be handled in a national court. The private nature of the proceedings and outcome, hallmark attributes of ISDS, is one of the most important differences when compared to national court proceedings.

23 UNCTAD 2020. Of known ISDS cases, the rules account for $85 \%$ of cases, $53 \%$ and $32 \%$ respectively. 24 ICCA-Queen Mary 2018, s. 47.

25 ICCA-Queen Mary 2018, p. 57

26 Ibid., p. 50.

27 Eberhardt, Pia - Olivet, Cecilia: Profiting from injustice. How law firms, arbitrators and financiers are fuelling an investment arbitration boom. Corporate Europe Observatory and the Transnational Institute, 2012 (Eberhardt - Olivet 2012), p. 7.

28 von Goeler, Jonas: Third-party Funding in International Arbitration and its Impact on Procedure International Arbitration Law Library, Volume 35, Kluwer Law International, 2016, (von Goeler 2016) p. 54.

29 Ibid., p. 82-87.

30 Guven - Johnson 2019, s. 13.

\subsubsection{Disclosure of TPF}

Currently, according to ICSID and UNCITRAL arbitration rules, the ISDS investor claimant has no obligation to disclose that it has received TPF. Some have argued that this non-disclosure can create conflicts of interest between third-party funders and members of arbitral tribunals. The arbitrators do not have the opportunity to abstain on basis of conflict of interest if the real beneficiary of the dispute to be resolved is unclear. ${ }^{31}$ The parties may agree in the funding agreement between the funder and the claimant, for example, that the funder may, in return for its funding, define how the case should be handled and who the claimant investor should choose as the arbitrator for the case. ${ }^{32}$ Such financier stewardship and the lack of disclosure has been particularly debated due to the extremely limited number of experienced arbitrators involved in ISDS. ${ }^{33}$ These arbitrators often also maintain well-established professional relationships with ISDS financiers, which has been considered problematic due to possible conflicts of interest. ${ }^{\mathbf{3 4}}$

It is noteworthy that tribunals do already have extensive rights to request parties to disclose information regarding the proceeding. For instance, in ICSID case Muhammet Cap \& Sehil Insaat Endustri ve Ticaret Ltd. Sti. V. Turkmenistan, the arbitral tribunal ordered the claimants to disclose whether the claim was being funded by a third party, disclose the identity of the funder and the terms of the funding agreement. ${ }^{35}$ Although arbitrators often refer to earlier cases, there is no doctrine of precedent in international arbitration, meaning ISDS case law is non-binding and disclosure of TPF has therefore remained limited.

\subsubsection{Impact on the number of proceedings and settlement}

It has been argued that the use of TPF may increase the overall number of ISDS proceedings. With TPF, the claimant investor may initiate high-risk claims as the funder takes the financial risk on behalf of the claimant. ${ }^{36}$ Some studies have shown that TPF has increased the number of ISDS class actions. ${ }^{37}$

31 ICCA-Queen Mary 2018, p. 82

32 ICCA-Queen Mary 2018, p. 75-76.

33 See e.g. UNCTAD 2020. Of known ISDS cases, a small number of individuals have been appointed to over 20 proceedings, with some arbitrators involved in over 50 cases.

34 ICCA-Queen Mary 2018, p. 82.

35 Muhammet Cap \& Sehil Insaat Endustri ve Ticaret Ltd. Sti. V. Turkmenistan, ICSID ARB/12/6

36 Guven - Johnson 2019, p. 33

37 Lamm, Carolyn - Hellbeck, Eckhard R.: Third-party funding in international investment arbitration Introduction and Overview in Third-party Funding in International Arbitration. International Chamber of Commerce, 2013 (Lamm - Hellbeck 2013), p. 106. In the Stockholm Chamber of Commerce (SCC) case Quasar de Valores and Others v. Russia, SCC 24/2007, Russia was sued by a small group of shareholders of oil company Yukos due to tax sanctions that consequently led to the bankruptcy of Yukos. The shareholders' lawsuit was funded by the former main shareholder of the company, Menatep, with the intention of creating a favourable case to support its own claim. Menatep was later awarded $\$ 50$ billion in compensation. 
According to one study, TPF has increased the number of amicably resolved ISDS proceedings. ${ }^{38}$ However, due to a lack of available case material, little research has been conducted. ${ }^{39} \mathrm{~A}$ common concern is that especially middle-income and low-income countries are often poorly conditioned to deal with ISDS proceedings or even evaluate the grounds of the ISDS claim. ${ }^{\mathbf{4 0}}$ The mere participation of an experienced third-party funder in the claim may lead to increased willingness of the respondent state to settle the matter. ${ }^{41}$ As the investor claimant receives access to the funder's expertise and networks, the respondent state usually has to invest an equivalent financial stake in order to defend. ${ }^{42}$ Subsequently, this raises the costs of both parties, and explains the immense amount of expenses usually incurred in ISDS arbitration proceedings.

In Philip Morris v. Uruguay, the amount of the investor's claim for compensation was almost the same as the legal costs incurred in the ISDS proceeding itself. ${ }^{\mathbf{4 3}}$ The case was exceptional, because it is one of the few examples where a state has received TPF. The TPF was provided by not-for-profit financiers to support Uruguay in its defence tightening the country's tobacco regulation. Such arrangements remain rare and have mainly been limited to cases where the funder has a political or other procedural interest in the matter. ${ }^{\mathbf{4 4}}$ Therefore, low-income countries do not, in principle, receive for-profit TPF to defend their legislative measures against ISDS claimants, as the funding is seldom financially profitable.

The growth of number of cases resolved amicably has highlighted the need for regulation of TPF. According to statistics, almost $90 \%$ of investor claimants emanate from high-income countries, whereas only over a fourth of respondent states were high-income. ${ }^{45}$ As middleincome and low-income countries may have difficulties to assess their chances of success in an individual case and the cost of the arbitration, settling the case may be the simplest solution

38 Chen, Daniel L.: Can Markets Stimulate Rights? On the Alienability of Legal Claims. 46 Rand Journal of Economics, 2015, p. 49-50.

39 ICCA-Queen Mary 2018, p. 204

40 See e.g. UNCITRAL A/CN.9/WG.II/WP.147, 11 April 2018, Comments by the Government of Thailand, p. 4.

41 Sharp, Geoff - Marsh, Bill (ed.): A New Seat at the Mediation Table? The Impact of Third-Party Funding on the Mediation Process (Part 2). Kluwer Mediation Blog, Wolters Kluwer, 1 April 2017, http://mediationblog. kluwerarbitration.com/2017/04/01/7498/ (Sharp - Geoff 2020). Accessed 7 November 2020.

42 Sharp-Geoff 2O2O, p. 75.

43 Philip Morris v. Uruguay, ICSID ARB/10/7. In the case, the cigarette and tobacco manufacturing company filed a case against Uruguay due to government proposals for stricter tobacco regulation. There are fears that the threat of similar lawsuits could have a chilling effect on tobacco regulation reforms especially that the threat of similar lawsuits could have a chilling effect on tobacco regulation reforms especially
in middle-income and low-income countries. See. e.g. Brekoulakis, Stavros - Rogers, Catherine: Thirdin middle-income and low-income countries. See. e.g. Brekoulakis, Stavros - Rogers, Catherine: ThirdOctober 2019 (Brekoulakis - Rogers 2019), p. 25

44 Brekoulakis - Rogers 2019, p. 7.

45 Samples, Tim R.: Winning and Losing in Investor-State Dispute Settlement. American Business Law Journal, Volume 56, Issue 1, 2019, p. 143 for the state, even if the case was frivolous. ${ }^{46}$ Assessing chances of success is also hampered by the fact that the arbitral precedent is non-binding, and there is no direct right of appeal of the arbitration award under the ICSID rules. ${ }^{47}$

\subsubsection{Funder conduct in ISDS proceedings}

With sophisticated economic modelling and accumulated arbitrational expertise, the funder can assess whether investment in an ISDS claim is profitable. According to some estimates, only one in ten investors that apply for TPF will receive funding. ${ }^{48}$ Third-party funders are often specialised financial companies with vast investments in ISDS proceedings. The funder may also diversify their individual case risk with so-called portfolio financing, in which various claims are combined into a financial portfolio. The success of the portfolio is measured by the joint success of the proceedings. ${ }^{49}$

Some argue that portfolio financing exemplifies the risks that financiers may be willing to take to maximise profits, as it allows the funder to take massive risks in individual cases that are counterbalanced with ISDS proceedings with reduced risk. Permissibility of TPF has been defended with the assumption that only valid cases are funded, but it may be argued that in the international financial markets many frivolous cases will ultimately find funding due to high-risk, high-reward mentality. ${ }^{\mathbf{5 0}}$ In high-risk cases, the terms of the funding agreement between the investor and the funder are strictly agreed to protect the interests of the funder. ${ }^{\mathbf{5 1}}$ According to some financiers, significant risks should be taken when choosing cases to maximise profit. ${ }^{\mathbf{5 2}}$

TPF also raises questions regarding the choice of law of the proceeding as the funder is often established in a third country. The investor claimants also often draw up the funding agreement with a separate SPV established by funder companies. Questions arise, for example, as to which law applies to the arbitration, the funding agreement and the legal services provided, and if the SPV has at least some level of decision-making power over the proceeding, which effect this change of beneficiary has on the choice of law. ${ }^{\mathbf{5}}$ In the case Teinver v. Argentina, the arbitral tribunal found that the entry of a funder to the proceeding was not problematic, as it occurred after the commencement of the arbitration. According to the case, subsequent verification of

46 Guven - Johnson 2019, p. 34

47 Ibid., p. 34.

48 ICCA-Queen Mary 2018, p. 25

48 ICCA-Queen 49 Ibid.,p. 203.

$50 \mathrm{Ibid} .$, p. 254. According to one financier, many cases that are rejected in the financier's risk assessment process as very high-risk and unmeritorious nevertheless end up as ICSID procedures funded by other financiers.

51 Eberhardt - Olivet 2012, p. 59

52 Ibid.

53 Lamm - Hellbeck 2013, p. 104-106. See e.g. ICSID cases CSOB v. Slovak Republic and Loewen v. United States. 
jurisdiction is not performed. ${ }^{\mathbf{5 4}}$ The subsequent funder-investor relations and their effect on jurisdiction can cause confusion in the context of international financial markets, as the original third-party funder may refinance the case and redistribute risks with a set of new financial instruments, further obscuring actual beneficiaries of the case..$^{\mathbf{5 5}}$

\subsubsection{Distribution of costs}

Sharing the costs of arbitration may also create problematic situations in the proceeding. Currently, no regulation nor ISDS arbitral precedent principles regarding sharing the costs of third-party funded arbitration exist, ${ }^{\mathbf{5 6}}$ even in situations where the third-party funder has been active in evoking the claim. ${ }^{57}$ Thus, the decision regarding the costs is left to the discretion of the arbitral tribunal, which means that the claimant and the respondent state may have to pay their own legal costs even if the claim funded by the third-party funder is unsuccessful. In arbitral precedent, TPF has not been recognised as a factor that would affect the apportionment of costs. As states do not have a direct right to initiate counterclaims under investment treaties, the respondent state may not be entitled for compensation for its legal costs, even when the claim has been frivolous. ${ }^{58}$

There is also a lack of regulation regarding security for costs as an interim measure. Currently, the investor receiving TPF is not required to pay a deposit to cover the state's legal costs, were the claimant to lose the case. According to some opinions, the mere fact that the claimant has to rely on TPF is evidence that the security for costs is justified. ${ }^{\mathbf{5 9}}$ In the ICSID case S\&T Oil $v$. Romania, the respondent state was unaware that the claimant was receiving TPF. ${ }^{60}$ If the state had been aware of the funding in the case, it would have applied for a security for costs to ensure the claimant's solvency in the case the claim would be unsuccessful. Security for costs would be necessary to ensure payment of the adverse award, particularly in situations where the funder has established an SPV with limited capital. ${ }^{61}$ The ordering of security for costs has been rare in ISDS awards, as tribunals have often invoked detailed grounds for refusal. ${ }^{62}$ The conditions for ordering a security have been very strict, and have mainly been limited to cases where a claimant has previously refused to pay the adverse costs award. ${ }^{\mathbf{6 3}}$

54 Teinverv. Argentina, ICSID ARB/09/1.

55 Eberhardt - Olivet 2012, p. 58

56 See e.g. ICSID case loannis Kardassopoulos and Ron Fuchs v. Georgia, ICSID Case No. ARB/07/15, where it is stated that no principles regarding distribution of costs in previous TPF cases exist.

57 Lamm - Hellbeck 2013, p. 107.

58 ICCA-Queen Mary 2018, p. 203

59 Ibid, p. 203.

59 Ibid, p. 203.

60 SeT OIV.Romania.

61 Veljanovski 2012, p. 430. SPV's are established especially due to insolvency reasons.

62 Brekoulakis - Rogers, p. 17-18. In arbitral precedent, the fact that the respondent state has e.g. not been able to prove the insolvency of the investor claimant has been a ground for refusa.

63 ICCA-Queen Mary 2018, p. 174

\subsection{Opposition to TPF regulation}

Regulatory proposals of TPF have also been criticised, mainly by funders, as overreaching and unnecessary. ${ }^{64}$ The main advantages of arbitration as opposed to national court processes are flexibility and speed that are meant to streamline the proceeding. It may be argued that disclosing TPF is not necessary, as it is the state that has caused circumstances that force the investor to invoke ISDS. ${ }^{65}$ The fact that the investor would have to use its funds to go forward with litigation is ultimately detrimental to the claimant's business. Many funders and arbitrators have also claimed that TPF has not been a major issue in ISDS, and no situations of conflict of interest have incurred. ${ }^{66}$ According to one funder, TPF should not be regulated, as there have been very few issues, notwithstanding the multi-billion dollar market value of the third-party litigation financing industry, ${ }^{67}$ although e.g. S\&T Oil v. Romania exemplified that there is limited information available regarding funding agreements and various issues they may cause. One funder has also commented that TPF should not be regulated, as funders also fund respondent states. ${ }^{68}$ However, funding provided to states is costly and remains uncommon.

It has also been suggested that the disclosure obligation could lead to situations where the state can, with unfounded action, prolong the arbitration proceedings by requesting unnecessary details of the funding agreement and the impact of the agreement on the proceeding. ${ }^{\mathbf{6 9}}$ Practices regarding confidentiality and legal privilege vary in civil law and common law jurisdictions, and the disclosure of protected documents may be solely at the discretion of the parties. ${ }^{70}$ If the party does not disclose the funding agreement despite the request of the tribunal, this may be relevant to the reasoning of the award.

Some have also argued that the wide definition of funding leaves too much room for interpretation, as the complexity of financial instruments may lead to situations where the funding is not prima facie received for ISDS proceeding purposes. ${ }^{\mathbf{7 1}}$ One example would be a situation where the thirdparty funder purchases a majority holding of the claimant investor's company, simultaneously obtaining control of the board of directors of the investor company. ${ }^{\mathbf{7 2}}$ In this case, the thirdparty funder is not a "non-party" of the proceeding, but a shareholder of the investor company

64 See e.g. ICSID: Compendium of State and Public Comments on WP \#1, 15 March 2019, https://icsid. worldbank.org/sites/default/files/amendments/Compendium_Comments_Rule_Amendment_3.15.19. pdf (ICSID Compendium on WP \#1) , p. 154-179. Accessed 7 November 2020

65 Brekoulakis - Rogers 2019, p. 1

66 See e.g. Burford Capital: Comments on the Proposed Amendments to the ICSID Rules, 28 December 2018 (Burford Capital 2018), p. 6

67 See e.g. Woodsford Litigation Funding: Response to Consultation on ICSID Rules, 31 March 2017.

68 Eberhardt-Olivet 2012 p. 60

69 See e.g. Judge Charles N. Brower: Comments to ICSID's proposed Chapter III. 16 December 2018, p. 3 and Möller, Gustaf: Comments on ICSID Rules Amendments - AR Rules. 2O-22. 27 December 2018

ICCA-Queen Mary 2018, p. 138

71 Burford Capital 2018, p. 5

72 Brekoulakis - Rogers 2019, p. 6. 
The assessment of the issue remains with the arbitral tribunal that should determine whether acquisition of the company's ownership is TPF. The tribunal must also consider the condition of dependent remuneration when assessing aforesaid arrangements.

\section{ICSID, UNCITRAL AND THE PROPOSED REGULATION OF TPF}

\section{I ICSID proposals}

As already mentioned above, majority of ISDS proceedings are resolved under the rules of ICSID in institutional arbitration. ${ }^{73}$ The popularity of ICSID rules compared to other arbitrational rules is based on several factors. The ICSID proceeding is completely independent and arbitration awards are with some exceptions final and binding, and national courts or other external bodies may not assess the legality of the award..$^{\mathbf{7 4}}$ Arbitration awards and monetary compensation therein must be recognised in each ICSID Convention member state in the same way as judgments of last instance. ${ }^{75}$

The ICSID rules do not currently regulate TPF, but ICSID has proposed changes in the rules regarding TPF as part of a comprehensive modernisation project. Its timetable remains unclear due to the COVID-19 pandemic. ${ }^{\mathbf{7 6}}$ The ICSID proposals define TPF through a disclosure obligation as follows:

"A party shall file a written notice disclosing the name and address of any non-party from which the party, directly or indirectly, has received funds for the pursuit or defense of the proceeding through a donation or grant, or in return for remuneration dependent on the outcome of the proceeding ("third-party funding")."77

The ICSID definition mimics the definition developed by ICCA. Furthermore, the claimant is required to notify ICSID of any changes to the information of the notice. There is no direct sanction for violating the disclosure obligation, but the tribunal may take the violation into account when determining the apportionment of costs. The rules do not require disclosure of information regarding the funding agreement unless the tribunal deems it necessary during the proceeding. In addition, the rules provide that TPF by itself is not sufficient to justify an order for security for costs but may form part of such evidence to order the security. ${ }^{\mathbf{7 8}}$

73 Dolzer - Schreuer 2012, p. 238.

74 Ibid., p. 239 .

75 Reed, Lucy - Paulsson, Jan - Blackaby, Nigel: Guide to ICSID Arbitration. 2nd edition, Kluwer Law International, 2010.

76 ICSID: Proposals for Amendment of the ICSID Rules, Working Paper \#4, Volume 1, February 2020 (ICSID Working Paper \#4), p. 1.

77 ICSID Working Paper \#4, p. 37.

78 Ibid., p. 58-59.
The ICSID regulation proposals favour transparency and case-by-case measures instead of strict regulation. In ICSID working papers it is stated that the sole purpose of the disclosure obligation is to avoid conflicts of interest, and that disclosure requirement of contents of the funding agreement is not part of the regulatory reform. ${ }^{79}$ According to ICSID, the rules regarding disclosure of confidential information may already prevent the disclosure of the conditions of the funding agreements during proceedings. ${ }^{\mathbf{8 0}}$

\subsection{How have the ICSID proposals been criticised?}

The ICSID proposals have been seen by many as insufficient to regulate TPF, as the reform takes no position on many aspects of TPF, such as the right of the funder to define and direct action of the claimant investor. ${ }^{\mathbf{8 1}}$ In the proposals, ICSID justifies the changes through existing regulation and established arbitral precedent. In several sections of the ICSID working papers it is stated that proposals made by various ICSID member states are inconsistent with praxis and existing TPF regulation. ${ }^{82}$ The working papers also state in several passages that the tribunal is already entitled to decide on certain matters, which member states have required to be regulated. ${ }^{\mathbf{8 3}}$

The ICSID secretariat has not deemed it necessary to consider prohibition of TPF in ISDS despite demands by several countries. ICSID has focused mainly on the transparency of TPF but some suggest that the mere increase in transparency is not sufficient to solve various major issues of TPF, ${ }^{84}$ such as the rise in amicably settled cases where the investor claimant has received TPF. Despite many proposals and criticism by various countries, including both low- and highincome countries, ${ }^{85}$ ICSID has opted not to create a requirement of direct disclosure of the funding agreement. ICSID argues that there is no need for rules regarding disclosure because the practice of disclosing the funding agreement has not been widely demanded or established as a precedent in arbitration, and that current arbitration rules nor investment treaties do not require the disclosure of the funding agreement. ${ }^{86}$ Furthermore, ICSID justifies the proposals with investment treaties drawn up by high-income countries, such as the Comprehensive

79 ICSID Working Paper \#1, p. 136.

80 Ibid.

81 Guven - Johnson 2019, p. 43.

82 ICSID Working Paper \#1, p. 133 and p. 262; ICSID: Proposals for Amendment of the ICSID Rules, Working Paper \#2, Volume 1, March 2019 (ICSID Working Paper \#2), p. 122.

83 ICSID Working Paper \#1, p. 138

84 See e.g. Codeco, Rafael Ramos - Sachetim, Henrique Martins: ICSID Rule Amendment: An attempt to remedy some of the concerns regarding ISDS identified by UNCITRAL WG III. Investment Treaty to remedy some of the concerns regarding ISDS identified by UNCITRAL WG III. Investment Treaty News, International Institute for Sustainable Development, O2 October 2019, https://www.lisd.
en/ (Analysis -> Quarterly Journal Archives -> October 2019). Accessed 7 November 2020.

85 Submitted statements are available in ICSID Compendium on WP \#1 and ICSID: Compendium of State and Public Comments on WP \#2, 28.6.2019 (ICSID Compendium on WP \#2), https://icsid.worldbank. org/sites/default/files/amendments/State_Public_Comments_WP2.pdf. Accessed 7 November 2020. See e.g. ICSID Compendium on WP \#1 pp. 153-154, 162-163 and 167 and ICSID Compendium on WP \#2 pp. 63, 68 and 70.

86 ICSID Working Paper \#1, p. 136. 
Economic and Trade Agreement (CETA) free-trade agreement between Canada and the EU, the free-trade agreements between EU and Vietnam, EU and Singapore and the rules drafted by the Singapore International Arbitration Centre (SIAC). ${ }^{\mathbf{8 7}}$ Both the EU and Singapore have been pleased with the rules put forward by ICSID with Singapore commending the proposed regulation as "sufficiently flexible" ${ }^{88}$ In addition, various countries, including some in the EU that have not faced ISDS proceedings, have supported the proposals. ${ }^{89}$ The written statements of the United States or United Kingdom are not public although according to statistics, the majority of ISDS investor claims originate from these countries. ${ }^{90}$ Alongside the US and UK, most investor claims stem from various EU countries. ${ }^{91}$

In addition to proposals requiring the disclosure of the funding agreement, ICSID has ignored proposals regarding security for costs and disclosure obligation thereof, ${ }^{\boldsymbol{9 2}}$ direct sanctions for violation of TPF rules ${ }^{93}$ and a more precise definition of TPF. ${ }^{94}$ ICSID has reasoned its stance by maintaining that the arbitral tribunal already has a wide array of methods to address the issues raised. ${ }^{95}$ ICSID has clearly taken a defensive stance in the process, and pursues a result where the ICSID rules correspond to regulation already introduced in other international instruments to reach a harmonised approach to treatment of TPF. ${ }^{96}$

\subsection{How has UNCITRAL approached ISDS TPF regulation?}

ISDS proceedings resolved ad hoc under UNCITRAL Arbitration Rules account for approximately a third of known ISDS cases. ${ }^{97}$ UNCITRAL's regulatory process regarding TPF in ISDS is still at an early stage, but compared to ICSID, the process has progressed noticeably differently. In its working papers, UNCITRAL emphasises the need for research on TPF and its effects on ISDS to better understand the regulatory need. ${ }^{\mathbf{9 8}}$ UNCITRAL has set out to collect relevant data with the help of different groups, including investors and third-party funders. ${ }^{99}$ As in the ICSID regulation process, states have given varying proposals on how to regulate TPF. The UNCITRAL working papers assert that one of the aims is to reach a harmonised solution with ICSID TPF rules. ${ }^{100}$

87 Ibid., p. 136

88 ICSID Compendium on WP \#1, p. 166

89 ICSID Compendium on WP \#2, p. 71. According to statistics by UNCTAD, many ISDS investors emanate from Luxembourg. The country has favoured light regulation of TPF, citing financing needs of small and medium-sized enterprises.

90 UNCTAD 2020.

91 lbid.

92 ICSID Compendium on WP \#1, 15.3.2019, Comment by Panama, p. 166.

93 Ibid., Comment by China, p. 157 and Comment by Spain, p. 167.

94 Ibid., Comment by Georgia, p. 159, Comment by Spain, p. 167, Comment by Ukraine, p. 169

95 ICSID Working Paper \#2 2019, p. 121-123

96 ICSID Working Paper \#1, p. 135. The instruments mentioned by ICSID are mainly creations of highincome capital exporter countries.

97 UNCTAD 2020.

98 UNCITRAL: A/CN.9/1004, p. 18

99 lbid.

$100 \mathrm{lbid}$
However, the UNCITRAL proposals have been more vocal regarding frivolous claims. The biggest difference between the remarks made by UNCITRAL and ICSID is whether TPF should be limited to cases where the parties, particularly small and medium-sized enterprises, have insufficient resources to invoke the ISDS proceeding. ${ }^{101}$ The UNCITRAL proposals have also considered the role of mediation and TPF in ISDS. ${ }^{102}$ UNCITRAL has, when compared to the ICSID process, also explicitly addressed concerns put forward by countries, and has in its proposals referred to treaties in which TPF has been strictly regulated or completely banned. ${ }^{103}$ UNCITRAL has in the context of its overall reform considered establishment of a new advisory centre, that could offer low-cost advice and enable especially low-income countries to assess merits of ISDS claims. ${ }^{104}$

\section{CONCLUSION}

TPF implies many policy issues that demand deliberation and resolution in the context of ISDS. The timetable for the ICSID rules amendment process has been postponed later to 2021 due to the COVID-19 pandemic, ${ }^{\mathbf{1 0 5}}$ and proposed amendments to ICSID rules must be approved by a two-thirds majority by the Administrative Council of ICSID, which comprises of representatives of member states. The UNCITRAL process is also facing delays, with next meeting of the Working Group III planned for April 2021. ${ }^{106}$

Finding a unison approach to TPF regulation may seem like a laborious task due to the controversial and political nature of the practice. The issue is further complicated by lack of research data on TPF, and further deliberation will show whether this fundamental challenge can be resolved in the UNCITRAL process. In recent years, many developing countries have withdrawn or considered an exit from the ICSID Convention. ${ }^{107}$ It remains to be seen to what extent the final proposals are able to balance between investor and state interests regarding regulation amid increasing inquiry and criticism of the investment arbitration system.

101 UNCITRAL: A/CN.9/1004, p. 18-19.

102 lbid.

103 UNCITRAL: A/CN.9/WG.III/WP.172, p. 3.

104 UNCITRAL: A/CN.9/WG.II/WP.168

105 ICSID: Annual Report 2020, 21 September 2020, https://icsid.worldbank.org/sites/default/files/ publications/annual-report/en/ICSID_AR2O_CRA_Web.pdf, p. 4. Accessed 7 November 2020.

106 UNCITRAL: LA/TL 133 (3-7) 39th, p. 1

107 In recent years, Bolivia, Ecuador, and Venezuela have withdrawn from the ICSID Convention. In addition, many major developing countries such as India, Brazil and Russia have not ratified the ICSID Convention or acceded to the organisation. 